\title{
Studies on Water Transport through the Sweet Cherry Fruit Surface: VIII. Effect of Selected Cations on Water Uptake and Fruit Cracking
}

\author{
Holger Weichert, Carina von Jagemann, Stefanie Peschel, and Moritz Knoche ${ }^{1}$ \\ Institute for Agronomy and Crop Science, Department of Horticulture, Martin-Luther-University of \\ Halle-Wittenberg, D-06099 Halle (Saale), Germany \\ Dieter Neumann \\ Institute of Plant Biochemistry, Weinberg 3, D-06120 Halle (Saale), Germany \\ Wilfried Erfurth \\ Max-Planck Institute of Microstructure Physics, Weinberg 2, D-06120 Halle (Saale), Germany
}

\begin{abstract}
ADDITIONAL INDEX WORDS. Prunus avium, cuticle, permeance, water conductance, splitting
ABSTRACT. Water uptake through the exocarp of intact sweet cherry [Prunus avium (L.)] fruit was determined gravimetrically in an immersion assay $\left(25^{\circ} \mathrm{C}\right)$. Fruit with sealed pedicel/fruit juncture were incubated in water during the first interval ( 0 to 0.75 hour) and in $10 \mathrm{~mm}$ salt solutions of selected cations during the second (0.75 to 1.5 hours) and third interval (1.5 to 2.25 hours) of an experiment. Rates of water uptake (F) were calculated for first, second and third intervals (FI, FII and FII, respectively) and salt effects indexed by the ratios $\mathrm{FI}^{\mathrm{II}} / \mathrm{FI}^{\mathrm{I}}$ and $\mathrm{F}^{\mathrm{II}} / \mathrm{F}^{\mathrm{I}}$. $\mathrm{AgNO}_{3}\left(\mathrm{~F}^{\mathrm{II}} / \mathrm{F}^{\mathrm{I}}=\mathbf{0 . 6 5}\right)$, $\mathrm{NaCl}(0.70), \mathrm{BaCl}_{2}(0.67), \mathrm{CdCl}_{2}(0.69), \mathrm{CuCl}_{2}(0.42), \mathrm{HgCl}_{2}(0.58)$, and $\mathrm{SrCl}_{2}(0.69)$, and the salts of trivalent cations $\mathrm{AlCl}_{3}(\mathbf{0 . 5 0}), \mathrm{EuCl}_{3}(\mathbf{0 . 5 8})$, and $\mathrm{FeCl}_{3}(0.49)$, significantly decreased water uptake into mature 'Sam' fruit as compared to the water control $(0.87)$. $\mathrm{KCl}(0.82), \mathrm{NH}_{4} \mathrm{Cl}(0.85), \mathrm{CaCl}_{2}(0.75), \mathrm{MgCl}_{2}(0.88), \mathrm{MnCl}_{2}(0.81)$, and $\mathrm{ZnCl}_{2}(0.72)$ had no effect, $\mathrm{LiCl}(1.00)$ increased uptake. Similar data were obtained for $\mathrm{F}$ II/FI. The effect of $\mathrm{FeCl}_{3}$ on water uptake was independent of the presence of $\mathrm{CaCl}_{2}, \mathrm{AlCl}_{3}$, or $\mathrm{CuCl}_{2}$, as sequential or simultaneous treatment with these salts reduced water uptake to the same extent as with $\mathrm{FeCl}_{3}$ alone. Increasing $\mathrm{FeCl}_{3}$ concentration up to 1 mu decreased uptake, higher concentrations had no further effect. $\mathrm{FeCl}_{3}$ and $\mathrm{CaCl}_{2}$ to a smaller extent decreased water uptake in developing 'Regina' sweet cherry fruit (55 to 91 days after full bloom). $\mathrm{FeCl}_{3}$ had no significant effect on water uptake along the pedicel/fruit juncture, but markedly reduced uptake through the exocarp of all cultivars investigated ('Burlat', 'Early Rivers', 'Hedelfinger', 'Knauffs', 'Regina', 'Sam', 'Summit', and 'Van'). Effects of $\mathrm{CaCl}_{2}$ on water uptake were limited to 'Burlat', 'Early Rivers', and 'Hedelfinger'. $\mathrm{CaCl}_{2}$ and $\mathrm{FeCl}_{3}$ both decreased fruit cracking, but $\mathrm{FeCl}_{3}$ was more effective. The mode of action of mineral salts in decreasing water uptake and fruit cracking and their potential for field use are discussed.
\end{abstract}

Rain-induced fruit cracking is a severe limitation to sweet cherry production world-wide. Fruit cracking is thought to be related to increased turgor resulting from water uptake into the fruit (Considine and Kriedemann, 1972; Sekse, 1998). Spray application of salt solutions and incubating fruit in salt solutions were reported to reduce fruit cracking under field and laboratory conditions. Most of these studies focused on Ca-salts (e.g., Bangerth, 1968; Callan, 1986; Christensen, 1996; Glenn and Poovaiah, 1989; Lang and Flore, 1999; Verner, 1937). Effects of $\mathrm{Ca}$-salts on fruit cracking were inconsistent. While cracking was decreased in some experiments (Callan, 1986; Lang and Flore, 1999), there was little or no effect in others (Koffmann et al., 1996; Looney, 1985). Less information is available on other salts. Bullock (1952) found cations in general, and the $\mathrm{Ca}, \mathrm{Cu}, \mathrm{Fe}, \mathrm{Al}$, $\mathrm{Th}$, and $\mathrm{U}$ cations in particular, to be more effective in reducing cracking than anions. Similar findings were reported for $\mathrm{Ca}, \mathrm{Fe}$,

\footnotetext{
Received for publication 5 Dec. 2003. Accepted for publication 14 Mar. 2004. This research was funded in part by grants from the Deutsche Forschungsgemeinschaft, the Saale Obst Erzeuger- und Absatzgenossenschaft, and the Gisela Foundation. We thank Kurt Ehm, Wolfgang Meyer, Monika Moehler, Werner Pfannenstiel, Erhard Sonnenkalb, and Brigitte Wiggert for providing fruit samples, Matthias Hinz, Evelyn and Ruth Richter for technical assistance and Alfred Blume and Peter D. Petracek for discussion and critical comments on an earlier version of this manuscript.

${ }^{1}$ To whom reprint requests should be addressed. E-mail address:

knoche@landw.uni-halle.de
}

and $\mathrm{Al}$ (Bangerth, 1968; Christensen, 1996). The authors hypothesized that reduced cracking resulted from cations cross-linking cell wall constituents, thereby improving mechanical properties of the exocarp. Recently, Beyer et al. (2002a) demonstrated that $\mathrm{FeCl}_{3}, \mathrm{Fe}\left(\mathrm{NO}_{3}\right)_{3}, \mathrm{Fe}_{2}\left(\mathrm{SO}_{4}\right)_{3}$, and $\mathrm{AlCl}_{3}$, but not $\mathrm{CaCl}_{2}$, markedly reduced water uptake by decreasing conductance of the fruit exocarp, and this effect may have contributed to reduced cracking. There is little published data on effects of other cations or interactions of cations on water uptake. If the mechanistic basis for salt effects on water uptake differed, a combined application of effective salts may yield superior performance than of either salt alone. Furthermore, from a practical point of view, it would be important to know whether salt effects are restricted to certain cultivars or specific stages of fruit development. Such information would be helpful in assessing the potential usefulness of field applications of mineral salts for reducing cracking.

The objectives of the present study therefore were to: 1) establish effects of cations and their interaction on water uptake and 2) characterize the effect of selected cations on water uptake and fruit cracking in selected sweet cherry cultivars.

\section{Materials and Methods}

Plant material. Sweet cherry fruit ['Burlat', 'Early Rivers', 'Hedelfinger', 'Knauffs', 'Regina', 'Sam', 'Summit', 'Van' all 
grafted on 'Alkavo' (Prunus avium) rootstocks] were collected from commercial orchards located near Eisleben and Beesenstedt, Germany, in 2001, 2002, and 2003. Except for 'Regina' fruit sampled between 55 and $91 \mathrm{~d}$ after full bloom (DAFB), fruit of all other cultivars were at the fully mature stage III. Fruit were inspected for uniformity and freedom from defects, transferred to the laboratory, processed on the day of picking (cracking indices) or within $24 \mathrm{~h}$ of picking for time course, concentration response, effect of developmental stage, penetration along the pedicel/fruit juncture, and cultivar comparisons. Fruit used for comparison of chlorides and interaction among salts were held for up to $59 \mathrm{~d}$ at $1.6 \pm 0.3{ }^{\circ} \mathrm{C}, 72 \pm 0.6 \%$ relative humidity and $\mathrm{CO}_{2}$ and $\mathrm{O}_{2}$ concentrations of $17.2 \pm 0.5 \%$ and $17.4 \pm 0.1 \%$. Analysis of pooled control treatments revealed a slight, significant decrease in rates of water uptake ( $\mathrm{F}$ for 0 to $0.75 \mathrm{~h}$ ) as storage duration (Time) increased $\left[\mathrm{F}\left(\mathrm{mg} \cdot \mathrm{h}^{-1}\right)=-0.014 \times\right.$ Time $(\mathrm{d})+3.04, r^{2}=0.03 * *, \mathrm{n}$ $=271(\mathrm{H}$. Weichert, unpublished data) $]$.

\section{Water uptake assays}

Effect Of Cations. Effects of univalent (Ag, $\left.\mathrm{K}, \mathrm{Li}, \mathrm{Na}, \mathrm{NH}_{4}\right)$, divalent ( $\mathrm{Ba}, \mathrm{Ca}, \mathrm{Cd}, \mathrm{Cu}, \mathrm{Hg}, \mathrm{Mg}, \mathrm{Mn}, \mathrm{Sr}, \mathrm{Zn}$ ), and trivalent cations $(\mathrm{Al}, \mathrm{Eu}, \mathrm{Fe})$ on water uptake through the exocarp of mature 'Sam' sweet cherry fruit were studied using an immersion assay $\left(25^{\circ} \mathrm{C}\right)$ and sequential treatments performed on an individual fruit basis. During the initial incubation period $(0$ to $0.75 \mathrm{~h})$, deionized water was used as the donor. At $0.75 \mathrm{~h}$, the water donor was replaced by a $10 \mathrm{~mm}$ salt solution (equivalent to an osmotic potential $\geq-0.10 \mathrm{MPa}$, calculated for a salt of a trivalent cation) that served as the donor for the two subsequent intervals ( 0.75 to $1.5 \mathrm{~h}, 1.5$ to $2.25 \mathrm{~h}$ ). Except for Ag, which was used as the nitrate, all other cations were used as chlorides because these are readily water soluble and the chloride anion does not interact with water conductance of the exocarp (Beyer et al., 2002a). Solutions were prepared shortly before use. Water uptake was restricted to the fruit exocarp by removing the pedicel by gently pulling and sealing the hole above the stony endocarp with silicone rubber (Dow Corning 3140 RTV coating; Dow Corning Corp., Midland, Mich.). This procedure eliminated uptake along the parallel pathway of the pedicel/fruit juncture (Beyer et al., 2002b). Water uptake was determined gravimetrically (BP 211 D; Sartorius AG, Göttingen, Germany). Briefly, fruit were removed from incubation solutions, blotted with soft tissue paper, then weighed and returned to the incubation vessel. Rates of uptake during first (FI, 0 to $0.75 \mathrm{~h}$ ), second (FII, 0.75 to $1.5 \mathrm{~h}$ ), and third intervals (FIII, 1.5 to $2.25 \mathrm{~h}$ ) were calculated and salt effects indexed by the ratio of flow rates $\left(\mathrm{FII}^{\mathrm{II}} / \mathrm{F}^{\mathrm{I}}\right.$ or $\left.\mathrm{FII} / \mathrm{FI}^{\mathrm{I}}\right)$ after replacing the water donor $\left(\mathrm{F}^{\mathrm{I}}\right)$ by a salt solution (FII, FIII). Using this procedure control and treatment effects are established sequentially on an individual fruit basis, thereby reducing fruit to fruit variation in response. Since fruit surface area and driving forces for water uptake remain essentially constant, effects of cations on the $\mathrm{F}^{\mathrm{II}} / \mathrm{F}^{\mathrm{I}}$ or $\mathrm{FIII} / \mathrm{FI}^{\mathrm{I}}$ ratio reflect effects on water permeability of the exocarp.

INTERACTIONS AMONG SALTS. Interactions among $\mathrm{CaCl}_{2} / \mathrm{FeCl}_{3}$, $\mathrm{CuCl}_{2} / \mathrm{FeCl}_{3}, \mathrm{HgCl}_{2} / \mathrm{FeCl}_{3}$, and $\mathrm{AlCl}_{3} / \mathrm{FeCl}_{3}$ on water uptake through the exocarp of mature 'Sam' fruit were established using the following sequences of donor solutions: $\mathrm{H}_{2} \mathrm{O} / \mathrm{salt} 1 / \mathrm{salt} 1$, $\mathrm{H}_{2} \mathrm{O} /$ salt $2 /$ salt $2, \mathrm{H}_{2} \mathrm{O} /$ salt $1 /$ salt $2, \mathrm{H}_{2} \mathrm{O} /$ salt $2 /$ salt $1, \mathrm{H}_{2} \mathrm{O} /$ salts $1+2 /$ salts $1+2, \mathrm{H}_{2} \mathrm{O} / \mathrm{H}_{2} \mathrm{O} / \mathrm{H}_{2} \mathrm{O}(\mathrm{n} \geq 7)$. Concentrations of individual salts were $10 \mathrm{~mm}$, except where both salts were used simultaneously (5 mм each). FII/FI, FIII/FI and FIII/FII were calculated and analyzed for interactions among salts on water uptake.

Time Course. The time course of water uptake into mature
'Regina' sweet cherry fruit was monitored during a 5-h incubation period in donor solutions containing $\mathrm{CaCl}_{2}$ or $\mathrm{FeCl}_{3}, \mathrm{H}_{2} \mathrm{O}$ only served as control. Pedicels were cut at 5-mm length, and pedicel and receptacle, but not pedicel/fruit juncture, sealed using silicone rubber. Osmolality of donor solutions, as determined by vapor pressure osmometry (model 5520; Wescor Inc., Logan, Utah), was maintained approximately constant. Molar concentrations and osmotic potentials were 30 and $25 \mathrm{~mm}$ and -0.18 and $-0.19 \mathrm{MPa}$ for $\mathrm{CaCl}_{2}$ and $\mathrm{FeCl}_{3}$, respectively. Water uptake was determined at $0,0.75,1.5,3$, and $5 \mathrm{~h}(\mathrm{n} \geq 16)$.

Concentration Response. The concentration response of $\mathrm{CaCl}_{2}$ and $\mathrm{FeCl}_{3}$ on water uptake into mature 'Regina' fruit was established at $0,0.025,0.25,1,2.5$, and $25 \mathrm{~mm}$ using the procedure described above. The pedicel/fruit juncture remained open $(\mathrm{n}=$ 17 and 7 for $\mathrm{CaCl}_{2}$ and $\mathrm{FeCl}_{3}$, respectively).

Duration OF INCUBATION. The effect of duration of incubating mature 'Summit' sweet cherry fruit in $10 \mathrm{~mm} \mathrm{FeCl}_{3}$ on water uptake through the exocarp was studied using the following experimental design. Initially ( 0 to $0.75 \mathrm{~h})$, fruit were incubated in water. The second interval $(0.75$ to $1.5 \mathrm{~h})$ comprised immersing fruit for 0 and $45 \mathrm{~min}, 1$ and $44 \mathrm{~min}, 5$ and $40 \mathrm{~min}, 15$ and 30 min, 30 and $15 \mathrm{~min}$, and 45 and $0 \mathrm{~min}$ in $10 \mathrm{~mm} \mathrm{FeCl}_{3}$ and $\mathrm{H}_{2} \mathrm{O}$, respectively. In the third interval ( 1.5 to $2.25 \mathrm{~h}$ ), $\mathrm{H}_{2} \mathrm{O}$ only served as the donor again. To avoid carryover from the $\mathrm{FeCl}_{3}$ solution into $\mathrm{H}_{2} \mathrm{O}$ when changing solutions during the second interval, fruit were removed from the $\mathrm{FeCl}_{3}$ solution and blotted before incubation in $\mathrm{H}_{2} \mathrm{O}$ resumed.

Water uPtake along Pedicel/Fruit Juncture. Penetration along the pedicel/fruit juncture in absence and presence of $\mathrm{FeCl}_{3}$ (10 mm) was studied using mature 'Sam' fruit that were sealed entirely with silicone rubber except for the pedicel/fruit juncture. Preliminary experiments established that the sum of rates of water uptake into fruit with pedicel/fruit juncture sealed (7.8 $\pm 1.1 \mathrm{mg} \cdot \mathrm{h}^{-1}, \mathrm{n}=10$ ) plus the rate of uptake into fruit that was sealed, except for the pedicel/fruit juncture $\left(8.5 \pm 0.8 \mathrm{mg} \cdot \mathrm{h}^{-1}, \mathrm{n}\right.$ $=20$ ), approximately corresponded to uptake into non-sealed control fruit $\left[18.2 \pm 3.3 \mathrm{mg} \cdot \mathrm{h}^{-1}, \mathrm{n}=12(\mathrm{H}\right.$. Weichert, unpublished data)]. These data indicate that there was little effect of silicone rubber on fruit turgor and, hence, driving force for water uptake must have remained essentially constant. The effect of $\mathrm{FeCl}_{3}$ was established using sequential treatments as described above and the salt effect indexed by the $\mathrm{FII}^{\mathrm{II}} / \mathrm{FI}^{\mathrm{I}}$ and $\mathrm{FIII} / \mathrm{FI}^{\mathrm{I}}$ ratios.

EFFects of Cultivars. To address a potential salt $\times$ cultivar interaction, effects of $\mathrm{CaCl}_{2}(30 \mathrm{~mm})$ and $\mathrm{FeCl}_{3}(25 \mathrm{~mm})$ on water uptake were established in 'Burlat', 'Early Rivers', 'Hedelfinger', 'Knauffs', 'Regina', 'Sam', 'Summit', and 'Van'. Water uptake was restricted to the exocarp by sealing the pedicel/fruit juncture. Effects of salts were established by performing sequential treatments on an individual fruit basis and salt effects indexed by the ratio $\mathrm{FI}^{\mathrm{II}} / \mathrm{FI}$ as described above. To allow uptake through the exocarp to be related to whole fruit uptake, the contribution of penetration along the pedicel/fruit juncture was quantified in a separate experiment. Pedicels ( $5 \mathrm{~mm}$ in length) and receptacle were coated with silicone rubber ("control"). In a second group, the pedicel was removed and the hole above the endocarp sealed. Uptake along the pedicel/fruit juncture was calculated by difference.

EFFect Of FRUIT DEVElopment. Response of developing ' $\mathrm{Re}$ gina' fruit to $\mathrm{CaCl}_{2}$ (30 mm) and $\mathrm{FeCl}_{3}(25 \mathrm{~mm})$ was established between stage II (55 DAFB) and the mature stage III (91 DAFB). The pedicel ( $5 \mathrm{~mm}$ in length) was sealed as described above; the pedicel/fruit juncture remained open $(n=10)$.

Fruit Cracking. Two samples of 25 fruit each ('Summit', 
'Hedelfinger', 'Van') were incubated in solutions of $\mathrm{CaCl}_{2}$ or $\mathrm{FeCl}_{3}$ at $25^{\circ} \mathrm{C}$. The pedicel at full length remained attached to the fruit. No silicone rubber was applied. At 2, 4, 6, and $10 \mathrm{~h}$, fruit were inspected by naked eye for macroscopically visible cracks. Fruit with one or several cracks were removed from solution and the experiments continued. Cracking indices (CI) were calculated according to Christensen (1996) for each of the two samples using Eq. 1:

$$
C I=\frac{(5 a+3 b+c) \cdot 100}{125}
$$

where a, b, and c represent the number of fruit cracked at 2, 4, and $6 \mathrm{~h}$. To establish relationships between fruit cracking and water uptake, effects of salts on water uptake were quantified in parallel experiments on fruit from the same harvest. Pedicels were coated with silicone rubber to facilitate blotting; the pedicel/fruit juncture remained not coated. The initial number of fruit incubated was 10 , of which a minimum of four ('Van'), eight ('Summit'), or nine ('Hedelfinger') remained macroscopically crack-free in the incubation assay.

Scanning ELECTRON Microscopy (SEM). Epidermal segments were excised from mature 'Van' and 'Hedelfinger' fruit used for determining cracking indices. Segments were fixed by incubating for $1 \mathrm{~h}$ in $3 \%(\mathrm{w} / \mathrm{v})$ glutaraldehyde in phosphate buffer at $\mathrm{pH} 7.4$, followed by $1 \mathrm{~h}$ in $1 \%(\mathrm{w} / \mathrm{v})$ osmium tetroxide in $40 \mathrm{~mm}$ acetate-veronal buffer containing $20 \%$ (v/v) $0.1 \mathrm{~N} \mathrm{HCl} \mathrm{(pH} \mathrm{7.4;}$ Palade, 1952). Subsequently, samples were dehydrated in an acetone series. Specimens were critical-point-dried in $\mathrm{CO}_{2}(\mathrm{CPD}$ 030; Balt-Tec AG, Balzers, Liechtenstein), mounted on alumina stubs, sputter-coated with carbon and gold (MED 010; Balt-Tec AG), and viewed using a JSM6340F (Jeol, Tokio, Japan) SEM at accelerating voltages of 5 or $8 \mathrm{kV}$.

Data Analysis. Following water uptake experiments, fruit were inspected for macroscopically visible cracks. Data from fruit that were cracked were excluded from the analysis. The specified number of single fruit observations refers to the minimum number of fruit that remained crack free (by macroscopic inspection) during experiments. Where meaningful, data were subjected to analysis of variance (ANOVA). ANOVA, multiple comparisons of means, and regression analysis were carried out using the Statistical Analysis System software package (version 8.02; SAS Institute Inc., Cary, N.C.). Data in figures are presented as means \pm SE of means.

\section{Results}

Effects on rates of water uptake differed among cations (Table 1). Salts of univalent cations had little effect except for $\mathrm{LiCl}$, $\mathrm{AgNO}_{3}$, and $\mathrm{NaCl}$, which increased $(\mathrm{LiCl})$ or decreased $\left(\mathrm{AgNO}_{3}\right.$ and $\mathrm{NaCl}$ ) uptake, respectively. Chlorides of the divalent cations $\mathrm{Cd}, \mathrm{Cu}, \mathrm{Hg}$, and $\mathrm{Sr}$ consistently decreased uptake. $\mathrm{BaCl}_{2}$ and $\mathrm{ZnCl}_{2}$ reduced uptake in only one of the two intervals. There was no effect of $\mathrm{CaCl}_{2}, \mathrm{MgCl}_{2}$, or $\mathrm{MnCl}_{2}$. All chlorides of trivalent cations significantly reduced uptake. $\mathrm{CuCl}_{2}, \mathrm{HgCl}_{2}, \mathrm{AlCl}_{3}$, and $\mathrm{FeCl}_{3}$ were most effective in decreasing water uptake among the salts tested.

The effect of $\mathrm{FeCl}_{3}$ on water uptake was independent of the presence of $\mathrm{CaCl}_{2}, \mathrm{CuCl}_{2}$, or $\mathrm{AlCl}_{3}$ (data not shown). Sequential or simultaneous treatments with $\mathrm{CuCl}_{2}$, or $\mathrm{AlCl}_{3}$ and $\mathrm{FeCl}_{3}$ had no significant effect on $\mathrm{FII}^{\mathrm{II}} / \mathrm{FI}^{\mathrm{I}}$, $\mathrm{FIII}^{\mathrm{II}} \mathrm{F}$, or $\mathrm{FIII} / \mathrm{FII}^{\mathrm{II}}$ as compared to treatment with either of the salts alone (data not shown). However, sequential or simultaneous application of $\mathrm{HgCl}_{2}$ and $\mathrm{FeCl}_{3}$
Table 1. Effect of selected salts (10 mM) on rates of water uptake (F) through the exocarp of mature 'Sam' sweet cherry fruit. Effect of salts were indexed by the ratio of flow rates $\left(\mathrm{FI}^{\mathrm{II}} / \mathrm{FI}^{\mathrm{I}}\right.$ or $\left.\mathrm{F}^{\mathrm{III}} / \mathrm{FI}^{\mathrm{I}}\right)$ after replacing the water donor $\left(\mathrm{F}^{\mathrm{I}}, 0\right.$ to $\left.0.75 \mathrm{~h}\right)$ by a salt solution $\left(\mathrm{F}^{\mathrm{II}}, 0.75\right.$ to $1.5 \mathrm{~h}$; Fil, 1.5 to $2.25 \mathrm{~h}$ ).

\begin{tabular}{lrcl}
\hline $\begin{array}{l}\text { Sequence of donor } \\
\text { in interval I, II, and III }\end{array}$ & $\mathrm{n}$ & $\begin{array}{c}\text { FI }^{\mathrm{II}} / \mathrm{F}^{\mathrm{I}} \\
\text { (ratio) }\end{array}$ & $\begin{array}{c}\mathrm{F}^{\text {III }} / \mathrm{F}^{\mathrm{I}} \\
\text { (ratio) }\end{array}$ \\
\hline $\mathrm{H}_{2} \mathrm{O} / \mathrm{H}_{2} \mathrm{O} / \mathrm{H}_{2} \mathrm{O}$ & 50 & $0.87 \mathrm{a}$ & $0.91 \mathrm{a}$ \\
$\mathrm{H}_{2} \mathrm{O} / \mathrm{AgNO}_{3} / \mathrm{AgNO}_{3}$ & 9 & $0.65 \mathrm{~b}$ & $0.75 \mathrm{~b}$ \\
$\mathrm{H}_{2} \mathrm{O} / \mathrm{KCl} / \mathrm{KCl}$ & 7 & $0.82 \mathrm{a}$ & $0.91 \mathrm{a}$ \\
$\mathrm{H}_{2} \mathrm{O} / \mathrm{LiCl} / \mathrm{LiCl}$ & 21 & $1.00 \mathrm{~b}$ & $1.03 \mathrm{~b}$ \\
$\mathrm{H}_{2} \mathrm{O} / \mathrm{NaCl} / \mathrm{NaCl}$ & 8 & $0.70 \mathrm{~b}$ & $0.82 \mathrm{a}$ \\
$\mathrm{H}_{2} \mathrm{O} / \mathrm{NH}_{4} \mathrm{Cl} / \mathrm{NH}_{4} \mathrm{Cl}$ & 10 & $0.85 \mathrm{a}$ & $0.90 \mathrm{a}$ \\
$\mathrm{H}_{2} \mathrm{O} / \mathrm{BaCl}_{2} / \mathrm{BaCl}_{2}$ & 7 & $0.67 \mathrm{~b}$ & $0.77 \mathrm{a}$ \\
$\mathrm{H}_{2} \mathrm{O} / \mathrm{CaCl}_{2} / \mathrm{CaCl}_{2}$ & 20 & $0.75 \mathrm{a}$ & $0.84 \mathrm{a}$ \\
$\mathrm{H}_{2} \mathrm{O} / \mathrm{CdCl}_{2} / \mathrm{CdCl}_{2}$ & 8 & $0.69 \mathrm{~b}$ & $0.63 \mathrm{~b}$ \\
$\mathrm{H}_{2} \mathrm{O} / \mathrm{CuCl}_{2} / \mathrm{CuCl}_{2}$ & 7 & $0.42 \mathrm{~b}$ & $0.36 \mathrm{~b}$ \\
$\mathrm{H}_{2} \mathrm{O} / \mathrm{HgCl}_{2} / \mathrm{HgCl}_{2}$ & 7 & $0.58 \mathrm{~b}$ & $0.38 \mathrm{~b}$ \\
$\mathrm{H}_{2} \mathrm{O} / \mathrm{MgCl}_{2} / \mathrm{MgCl}_{2}$ & 18 & $0.88 \mathrm{a}$ & $1.03 \mathrm{a}$ \\
$\mathrm{H}_{2} \mathrm{O} / \mathrm{MnCl}_{2} / \mathrm{MnCl}_{2}$ & 16 & $0.81 \mathrm{a}$ & $0.79 \mathrm{a}$ \\
$\mathrm{H}_{2} \mathrm{O} / \mathrm{SrCl}_{2} / \mathrm{SrCl}_{2}$ & 14 & $0.69 \mathrm{~b}$ & $0.68 \mathrm{~b}$ \\
$\mathrm{H}_{2} \mathrm{O} / \mathrm{ZnCl}_{2} / \mathrm{ZnCl}_{2}$ & 8 & $0.72 \mathrm{a}$ & $0.75 \mathrm{~b}$ \\
$\mathrm{H}_{2} \mathrm{O} / \mathrm{AlCl}_{3} / \mathrm{AlCl}_{3}$ & 17 & $0.50 \mathrm{~b}$ & $0.50 \mathrm{~b}$ \\
$\mathrm{H}_{2} \mathrm{O} / \mathrm{EuCl}_{3} / \mathrm{EuCl}_{3}$ & 12 & $0.58 \mathrm{~b}$ & $0.62 \mathrm{~b}$ \\
$\mathrm{H}_{2} \mathrm{O} / \mathrm{FeCl}_{3} / \mathrm{FeCl}_{3}$ & 54 & $0.49 \mathrm{~b}$ & $0.40 \mathrm{~b}$ \\
\hline
\end{tabular}

${ }^{\mathrm{z} M e a n}$ within columns followed by the letter $\mathrm{b}$ differ significantly from the water control by Dunnett's $t$ test, $P=0.05$. F , FII, and FII for the water control averaged $2.6 \pm 0.1,2.3 \pm 0.1$, and $2.4 \pm 0.2 \mathrm{mg} \cdot \mathrm{h}^{-1}$, respectively.

decreased $\mathrm{FII}^{\mathrm{II}} \mathrm{F}$, FIII/FI, and FIII/FII to a somewhat larger extent than either of the salts alone (Table 2). This effect, however, was small and only occasionally significant. Based on these data, toxicological considerations, and potential for field use, subsequent experiments focused on $\mathrm{FeCl}_{3}$ and $\mathrm{CaCl}_{2}$.

Water uptake into sweet cherry fruit increased linearly with time up to $5 \mathrm{~h}$ (Fig. $1 \mathrm{~A}$ ). $\mathrm{FeCl}_{3}$ decreased the rate of water uptake, but $\mathrm{CaCl}_{2}$ had no effect (Fig. 1B).

Increasing the concentration of $\mathrm{FeCl}_{3}$ up to $1 \mathrm{~mm}$ decreased rates of water uptake (Fig. 2). Concentrations of $\mathrm{FeCl}_{3}>1 \mathrm{~mm}$ produced little additional effect. Again, $\mathrm{CaCl}_{2}$ had no effect on water uptake.

A minimum incubation period in $\mathrm{FeCl}_{3}$ of $0.08 \mathrm{~h}(5 \mathrm{~min})$ was necessary to induce a detectable decrease in water uptake (Fig. 3 ). When fruit were exposed to $\mathrm{FeCl}_{3}$ for $0.25 \mathrm{~h}$ or longer, rates of uptake remained at the decreased level during subsequent incubation in water.

Uptake along the parallel pathway of the pedicel/fruit juncture was only little affected by $\mathrm{FeCl}_{3}$. The $17.5 \%$ and $13.4 \%$ decrease in $\mathrm{FII}^{\mathrm{II}} / \mathrm{FI}^{\mathrm{I}}$ and $\mathrm{FIII} / \mathrm{FI}^{\mathrm{I}}$ as compared to the water control was nonsignificant ( $P=0.055$ and 0.113 for $\mathrm{F}^{\mathrm{II}} / \mathrm{F}^{\mathrm{I}}$ and $\mathrm{F}^{\mathrm{III}} / \mathrm{F}^{\mathrm{I}}$, respectively).

Rates of water uptake differed between cultivars (Table 3). Highest rates were obtained in 'Van', 'Hedelfinger', and 'Burlat', the lowest in 'Early Rivers', 'Sam', and 'Summit'. Restricting penetration to the exocarp by sealing the pedicel/fruit juncture significantly decreased uptake on average by $46 \%$.

$\mathrm{CaCl}_{2}$ decreased water uptake through the exocarp only in 'Burlat', 'Early Rivers', and 'Hedelfinger' (Table 4). In contrast, $\mathrm{FeCl}_{3}$ was effective in essentially all cultivars except for 'Knauffs' $(P=0.06)$. Across all cultivars, the $\mathrm{FII} / \mathrm{FI}^{\mathrm{I}}$ ratio averaged 0.62 and 1.06 for $\mathrm{FeCl}_{3}$ and $\mathrm{H}_{2} \mathrm{O}$, respectively, equivalent to a $42 \%$ reduction in uptake through the exocarp. 
Table 2. Interaction of $\mathrm{HgCl}_{2}$ with $\mathrm{FeCl}_{3}$ on rates of water uptake (F) through the exocarp of mature 'Sam' sweet cherry fruit. Effect of salts were indexed by the ratio of flow rates $\left(\mathrm{F}^{\mathrm{II}} / \mathrm{F}^{\mathrm{I}}, \mathrm{F}\right.$.II/FI, FII/FII) calculated from flow rates during interval I ( $\mathrm{F}^{\mathrm{I}}, 0$ to $\left.0.75 \mathrm{~h}\right)$, II ( $\mathrm{F}^{\mathrm{II}}$, 0.75 to $1.5 \mathrm{~h}$ ) and III (FIII, 1.5 to $2.25 \mathrm{~h}$ ). Concentrations of salts were 10 mм except when used simultaneously ( $5 \mathrm{~mm}$ each).

\begin{tabular}{lrccc}
\hline $\begin{array}{l}\text { Sequence of donor } \\
\text { in interval I/II/III }\end{array}$ & \multicolumn{1}{c}{$\begin{array}{l}\text { FII } / \mathrm{F}^{\mathrm{I}} \\
\text { (ratio) }\end{array}$} & $\begin{array}{c}\text { FIII } / \mathrm{F}^{\mathrm{I}} \\
\text { (ratio) }\end{array}$ & $\begin{array}{c}\text { FIII / FII } \\
\text { (ratio) }\end{array}$ \\
\hline $\mathrm{H}_{2} \mathrm{O} / \mathrm{H}_{2} \mathrm{O} / \mathrm{H}_{2} \mathrm{O}$ & 10 & $0.93 \mathrm{a} \mathrm{a}^{\mathrm{z}}$ & $0.98 \mathrm{a}$ & $1.08 \mathrm{a}$ \\
$\mathrm{H}_{2} \mathrm{O} / \mathrm{FeCl}_{3} / \mathrm{FeCl}_{3}$ & 9 & $0.49 \mathrm{bc}$ & $0.44 \mathrm{bc}$ & $0.93 \mathrm{ab}$ \\
$\mathrm{H}_{2} \mathrm{O} / \mathrm{FeCl}_{3} / \mathrm{HgCl}_{2}$ & 10 & $0.47 \mathrm{bc}$ & $0.36 \mathrm{bcd}$ & $0.83 \mathrm{ab}$ \\
$\mathrm{H}_{2} \mathrm{O} / \mathrm{HgCl}_{2} / \mathrm{HgCl}_{2}$ & 10 & $0.67 \mathrm{~b}$ & $0.47 \mathrm{~b}$ & $0.71 \mathrm{bc}$ \\
$\mathrm{H}_{2} \mathrm{O} / \mathrm{HgCl}_{2} / \mathrm{FeCl}_{3}$ & 10 & $0.61 \mathrm{bc}$ & $0.27 \mathrm{~cd}$ & $0.45 \mathrm{c}$ \\
$\mathrm{H}_{2} \mathrm{O} / \mathrm{FeCl}_{3}+\mathrm{HgCl}_{2} / \mathrm{FeCl}_{3}$ & & & & \\
$\quad+\mathrm{HgCl}_{2}$ & 8 & $0.42 \mathrm{c}$ & $0.26 \mathrm{~d}$ & $0.68 \mathrm{bc}$
\end{tabular}

"Means separation within columns by Tukey's Studentized range test, $P$ $=0.05 . \mathrm{F}^{\mathrm{I}}, \mathrm{FII}^{\mathrm{II}}$, and $\mathrm{F}^{\mathrm{III}}$ for pooled water controls averaged $2.6 \pm 0.2,2.4$ \pm 0.2 , and $2.5 \pm 0.2 \mathrm{mg} \cdot \mathrm{h}^{-1}$, respectively.

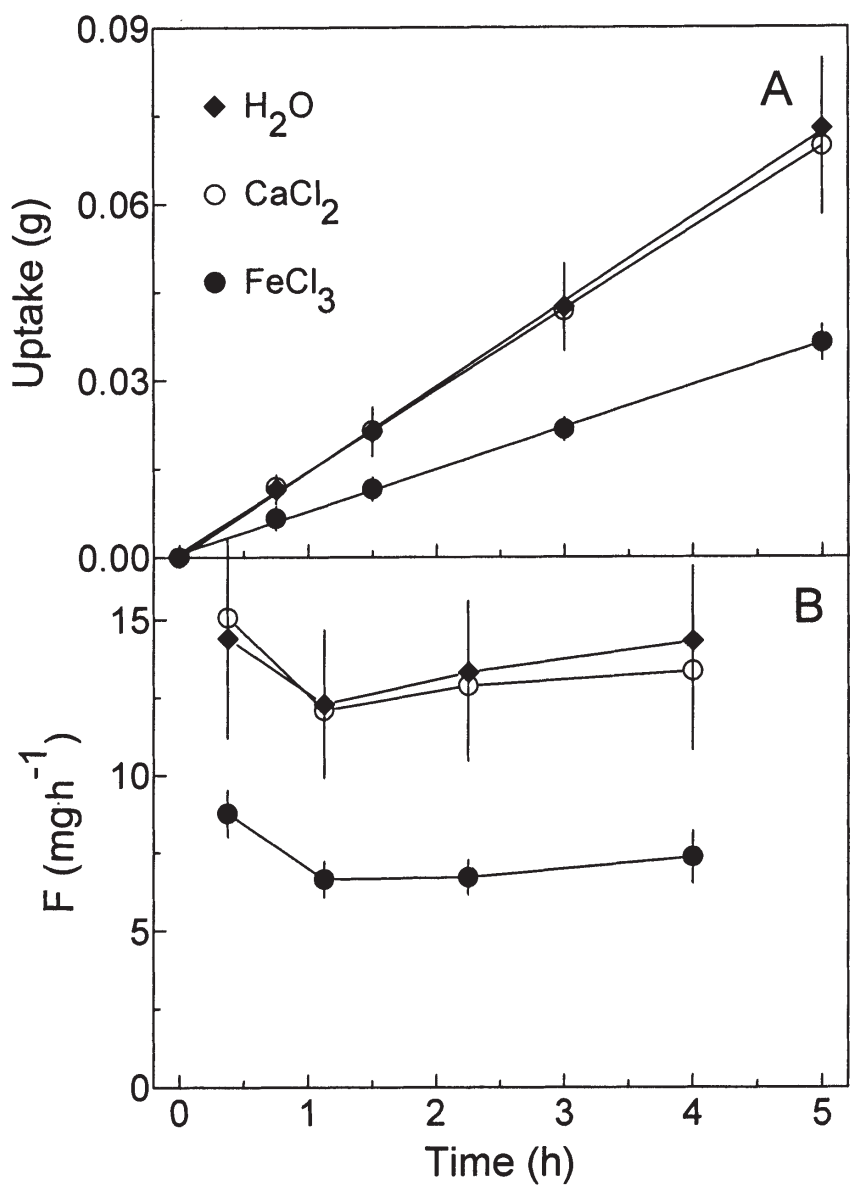

Fig. 1. Effect of $\mathrm{CaCl}_{2}$ and $\mathrm{FeCl}_{3}$ on the time course of water uptake into mature 'Regina' sweet cherry fruit. (A) Cumulative uptake. (B) Rate of uptake (F).

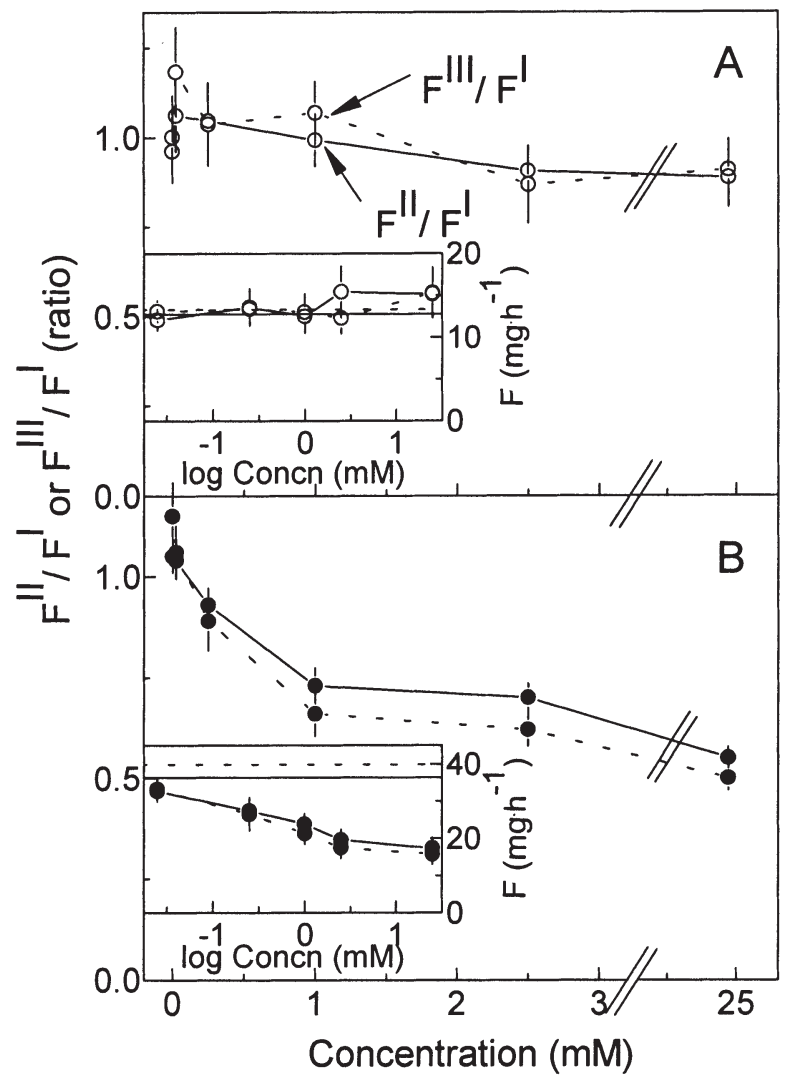

Fig. 2. Effect of concentration of $(\mathbf{A}) \mathrm{CaCl}_{2}$ and (B) $\mathrm{FeCl}_{3}$ on water uptake into mature 'Regina' sweet cherry fruit. Main graphs: Ratio of flow rates. Insets: Absolute rates of uptake $(F)$. Effect of salts were indexed by the ratio of flow rates $\left(\mathrm{FII}^{\mathrm{II}} / \mathrm{FI}^{\mathrm{I}}\right.$ or $\left.\mathrm{FIII} / \mathrm{FI}^{\mathrm{I}}\right)$ after replacing the water donor $\left(\mathrm{FI}^{\mathrm{I}}, 0\right.$ to $\left.0.75 \mathrm{~h}\right)$ by a salt solution (FII, 0.75 to $1.5 \mathrm{~h}$; FII, 1.5 to $2.25 \mathrm{~h}$ ). Horizontal solid and dashed lines in insets represent $\mathrm{FII}^{\mathrm{II}} / \mathrm{F}^{\mathrm{I}}$ and $\mathrm{FII} / \mathrm{FI}^{\mathrm{II}}$ ratios for the water control, respectively.

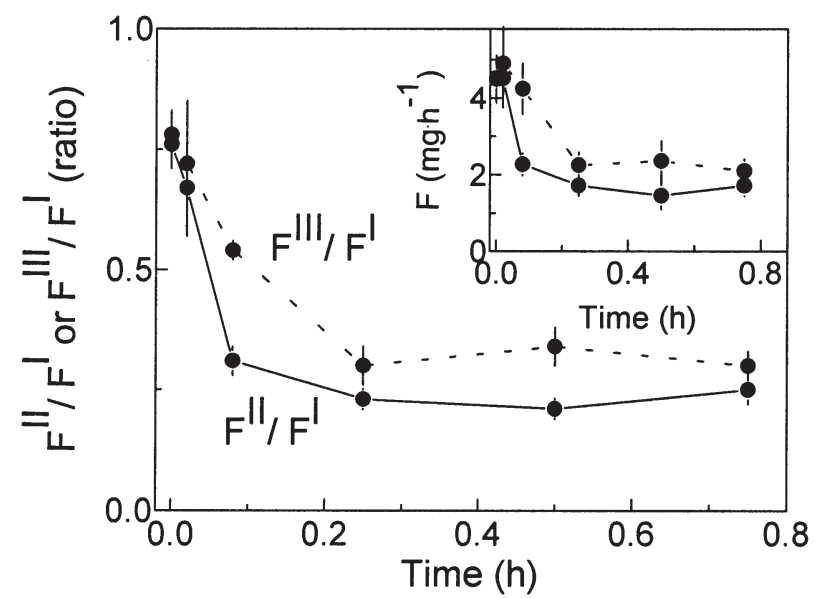

Fig. 3. Effect of duration of incubation of mature 'Summit' fruit in $\mathrm{FeCl}_{3}$ on water uptake through the exocarp. Rate of water uptake from a water donor during the first ( 0 to $0.75 \mathrm{~h}$ ) and third interval $(1.5$ to $2.25 \mathrm{~h}$ ) is referred to as FI and FIII. During the second interval $(0.75$ to $1.5 \mathrm{~h})$, fruit were incubated for 0 and $45 \mathrm{~min}, 1$ and $44 \mathrm{~min}, 5$ and $40 \mathrm{~min}, 15$ and $30 \mathrm{~min}, 30$ and $15 \mathrm{~min}$, and 45 and $0 \mathrm{~min}$ in $10 \mathrm{mM} \mathrm{FeCl}_{3}$ and $\mathrm{H}_{2} \mathrm{O}$, respectively, and the rate of uptake is referred to as FII. The effect of $\mathrm{FeCl}_{3}$ was indexed by the ratios $\mathrm{FI} / \mathrm{FI}$ and FII/FI. Main graph: Change in rates of uptake during phase II (FII/FI) and III (FII/ $\left./ \mathrm{FI}^{\mathrm{I}}\right)$ vs. duration of incubation in $\mathrm{FeCl}_{3}$. Insets: Absolute rates of water uptake during the second and third intervals. 
Table 3. Rates of water uptake (F, 0 to $3 \mathrm{~h}$ ) through exocarp and pedicel/fruit juncture in selected sweet cherry cultivars. Uptake through exocarp plus pedicel/fruit juncture was determined in fruit having the pedicel except for the pedicel/fruit juncture sealed with silicone rubber, uptake through the exocarp only in fruit with pedicel removed and hole above stony endocarp sealed. Penetration along the pedicel/fruit juncture was calculated by difference $(n \geq 4)$.

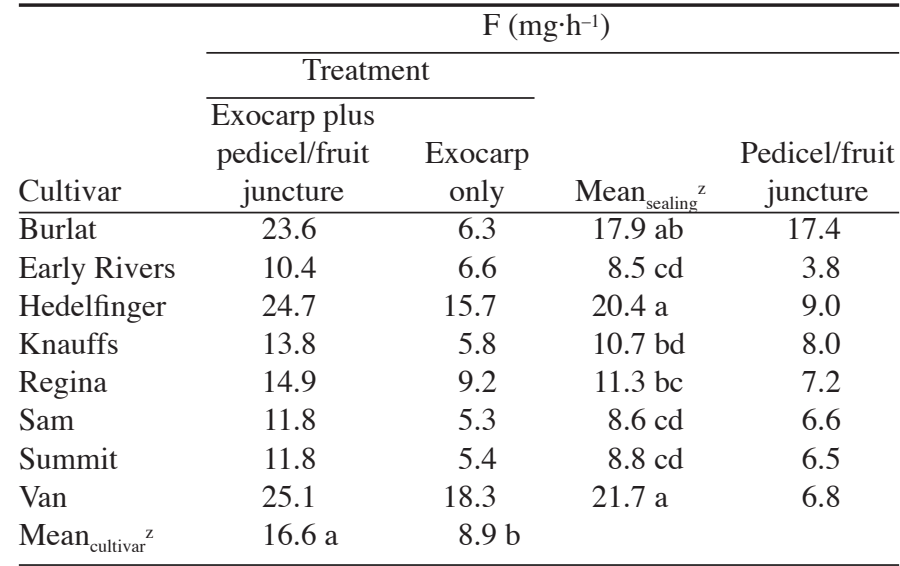

$\overline{{ }^{2} \text { Main effect cultivar and sealing pedicel/fruit juncture significant at } P}$ $=0.0001$. Interaction cultivar $\times$ sealing nonsignificant $(P=0.52)$. Mean separation by Tukey's Studentized range test, $P=0.05$.

Table 4. Effect of $\mathrm{CaCl}_{2}(30 \mathrm{~mm})$ and $\mathrm{FeCl}_{3}(25 \mathrm{~mm})$ on rates of water uptake $(\mathrm{F})$ through the exocarp in selected sweet cherry cultivars. Uptake was confined to the exocarp by removing the pedicel and sealing the hole above the stony endocarp with silicone rubber. Effects of salts were indexed by the ratio of flow rates $\left(\mathrm{F}^{\mathrm{II}} / \mathrm{FI}\right)$ after replacing the water donor $\left(\mathrm{F}^{\mathrm{I}}, 0\right.$ to $0.75 \mathrm{~h}$ ) by a salt solution $\left(\mathrm{F}^{\mathrm{II}}, 0.75\right.$ to $1.5 \mathrm{~h} ; \mathrm{n} \geq 6$ ).

\begin{tabular}{llcl}
\hline & \multicolumn{3}{c}{$\mathrm{F}^{\mathrm{II}} / \mathrm{F}^{\mathrm{I}}$ (ratio) } \\
\cline { 2 - 4 } Cultivar & $\mathrm{H}_{2} \mathrm{O}$ & $\mathrm{CaCl}_{2}$ & $\mathrm{FeCl}_{3}$ \\
\hline Burlat & $1.28 \mathrm{a}^{\mathrm{z}}$ & $0.92 \mathrm{~b}$ & $0.66 \mathrm{c}$ \\
Early Rivers & $1.08 \mathrm{a}$ & $0.87 \mathrm{~b}$ & $0.72 \mathrm{c}$ \\
Hedelfinger & $1.06 \mathrm{a}$ & $0.89 \mathrm{~b}$ & $0.47 \mathrm{c}$ \\
Knauffs & $0.98 \mathrm{a}$ & $0.73 \mathrm{a}$ & $0.61 \mathrm{a}$ \\
Regina & $1.13 \mathrm{a}$ & $1.15 \mathrm{a}$ & $0.50 \mathrm{~b}$ \\
Sam & $1.00 \mathrm{a}$ & $0.84 \mathrm{a}$ & $0.51 \mathrm{~b}$ \\
Summit & $0.87 \mathrm{a}$ & $0.87 \mathrm{a}$ & $0.57 \mathrm{~b}$ \\
Van & $0.95 \mathrm{a}$ & $0.88 \mathrm{a}$ & $0.48 \mathrm{~b}$ \\
Grand mean & 1.06 & 0.97 & 0.62 \\
\hline
\end{tabular}

${ }^{z}$ Main effects of cultivar and salts, and the interaction between cultivar and salts, are all significant. Mean separation within cultivars by Tukey's Studentized range test, at $P=0.05$.

There was no consistent change in water uptake between 55 and $91 \mathrm{DAFB}$, when mass of 'Regina' fruit increased from $1.8 \pm$ 0.0 (stage II) to $9.2 \pm 0.1 \mathrm{~g}$ (stage III; Fig. $4 \mathrm{~A}$ and B). Normalizing data for uptake in the water control revealed that $\mathrm{CaCl}_{2}$, and $\mathrm{FeCl}_{3}$ to a larger extent, decreased water uptake throughout fruit development. The effect of $\mathrm{CaCl}_{2}$ remained about constant, but the effect of $\mathrm{FeCl}_{3}$ increased up to $70 \mathrm{DAFB}$ and then decreased towards maturity (Fig. 4C).

When incubating 'Summit' (Fig. 5 A and C), 'Van' (Fig. 5E), or 'Hedelfinger' (data not shown) fruit in water, percentage of cracked fruit increased rapidly and approached $100 \%$ within $10 \mathrm{~h}$. $\mathrm{CaCl}_{2}$ decreased cracking at 2.5 and $25 \mathrm{~mm}$, but $\mathrm{FeCl}_{3}$ was more effective at both concentrations (Fig. 5A). The lowest effective $\mathrm{FeCl}_{3}$ concentrations were $1 \mathrm{~mm}$ ('Summit') and $2.5 \mathrm{~mm}$ ('Van' and 'Hedelfinger'), and higher concentrations resulted in greater

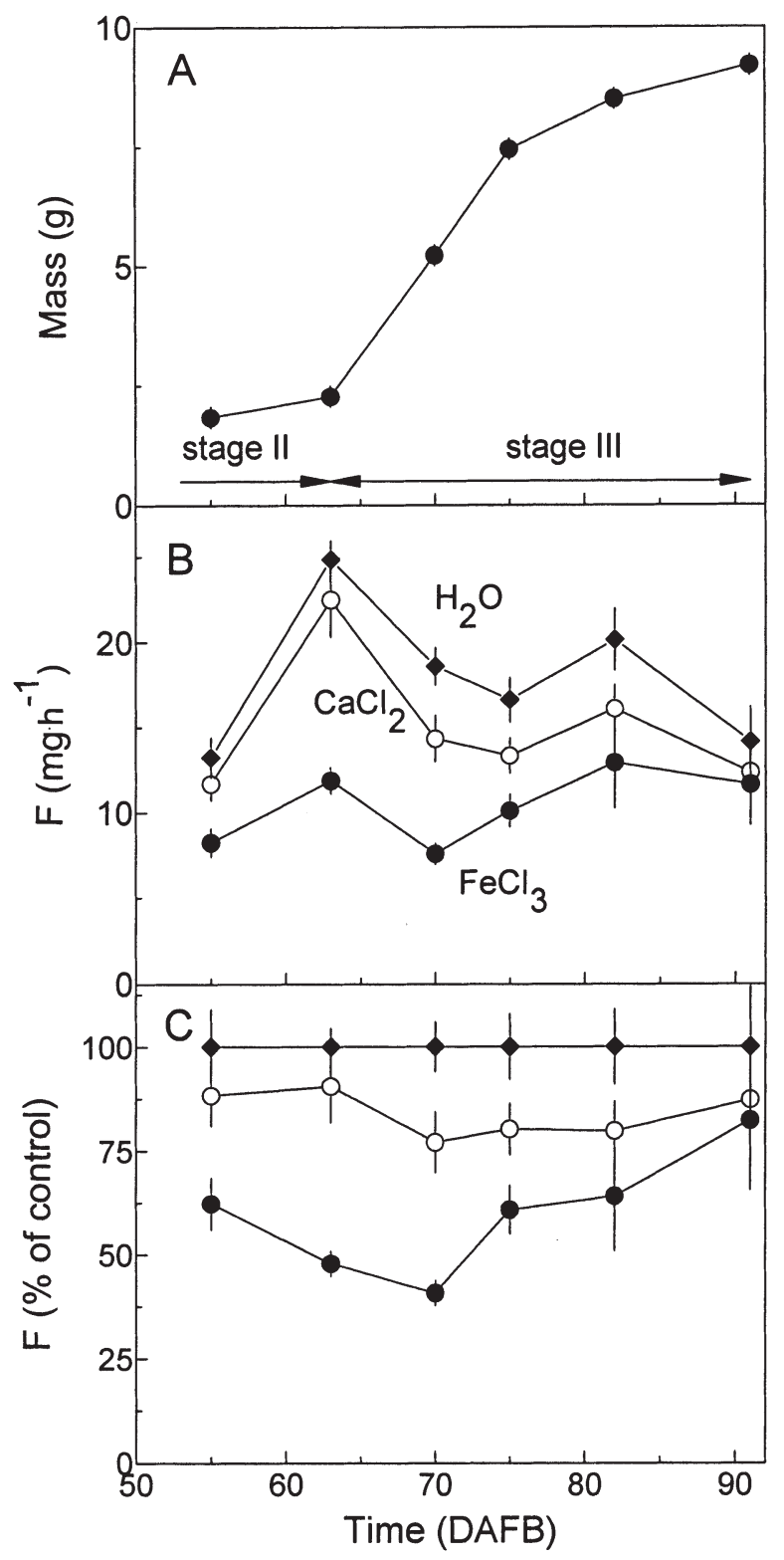

Fig. 4. (A) Time course of change in mass of developing 'Regina' sweet cherry fruit between 55 and $91 \mathrm{~d}$ after full bloom (DAFB). Arrows indicate duration of stages II and III of fruit development. (B, C) Effect of $\mathrm{CaCl}_{2}$ and $\mathrm{FeCl}_{3}$, on absolute $(\mathbf{B})$ and relative rates of water uptake $(\mathbf{C})$.

response (Fig. $5 \mathrm{C}$ and E; Table 5). Effects of salt concentration on water uptake into 'Summit' $\left(\mathrm{CaCl}_{2}, \mathrm{FeCl}_{3}\right)$, 'Van' $\left(\mathrm{FeCl}_{3}\right)$, or 'Hedelfinger' $\left(\mathrm{FeCl}_{3}\right)$ were qualitatively similar to those obtained with 'Regina' (data not shown, for 'Regina' see Fig. 2). Since data on water absorption were generated on fruit from the same batch as those used for determining cracking, cracking was analyzed as a function of the amount of water taken up. Fruit incubated in $\mathrm{CaCl}_{2}$ sustained higher water uptake without cracking than control fruit. This effect was even more pronounced with $\mathrm{FeCl}_{3}$. The amount of water taken up at a given percentage of fruit cracking increased with increasing $\mathrm{FeCl}_{3}$ concentrations (Fig. $5 \mathrm{~B}, \mathrm{D}$, and F).

It is important to note that appearance of fruit incubated in $\mathrm{FeCl}_{3}$, but not in $\mathrm{CaCl}_{2}, \mathrm{AlCl}_{3}$, or water, changed during the course of a cracking experiment. In the first 2 -h incubation interval, small 

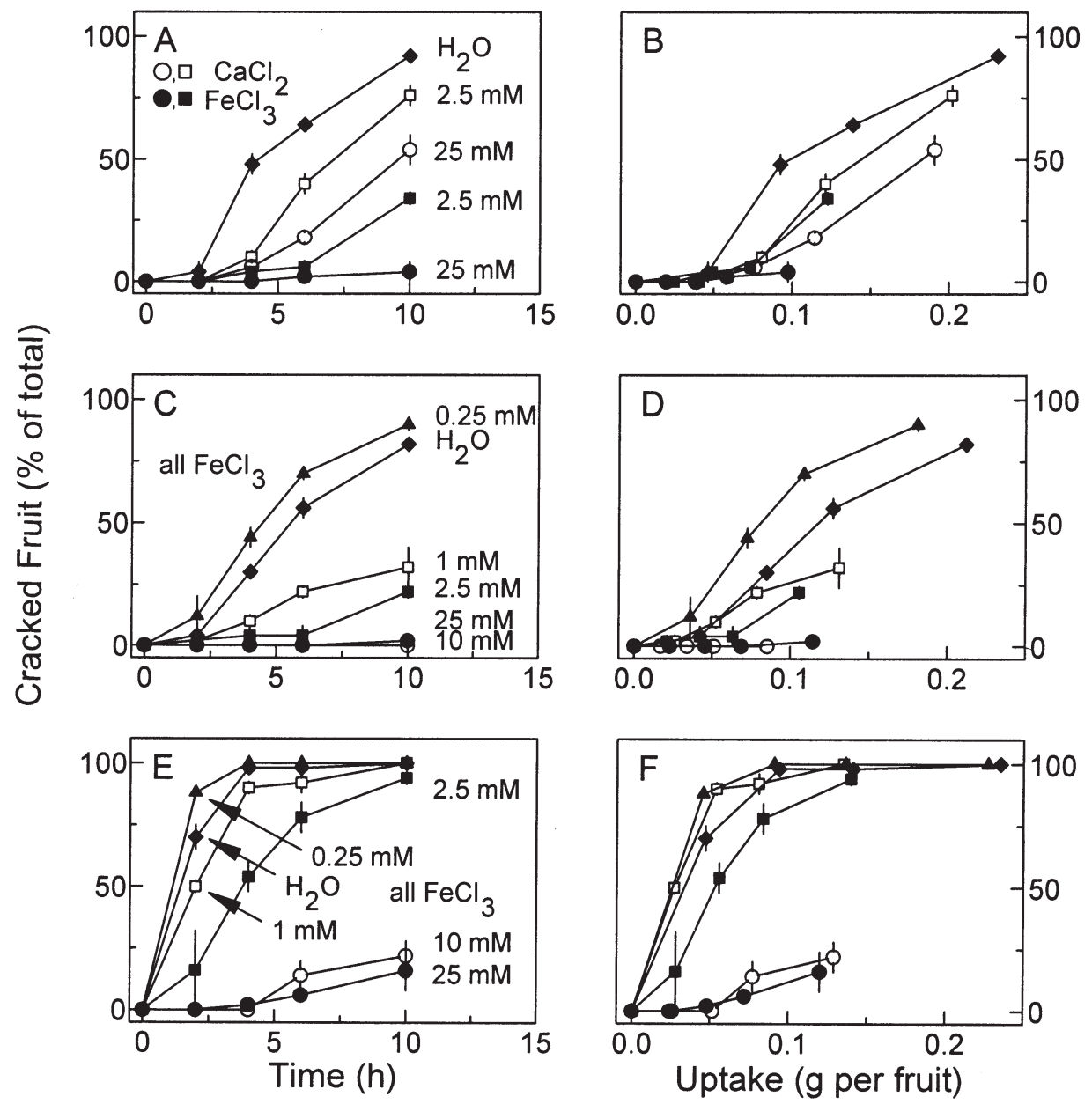

Fig. 5. Effect of $\mathrm{CaCl}_{2}$ and $\mathrm{FeCl}_{3}$ on cracking of 'Summit' (A to D) and 'Van' (E, F) sweet cherry fruit. (A, C, E) Time course of cracking. (B, D, F) Relationship between percentage of fruit cracked and amount of water taken up. For cracking indices see Table 5.

Table 5. Effect of $\mathrm{CaCl}_{2}$ and $\mathrm{FeCl}_{3}$ on cracking indices (CI) of 'Hedelfinger', 'Summit' and 'Van' sweet cherry fruit. CI were calculated from percentage of fruit cracked at 2, 4, and $6 \mathrm{~h}$.

\begin{tabular}{lccccc}
\hline & Concn & \multicolumn{5}{c}{ CI } \\
\cline { 3 - 6 } Donor & $(\mathrm{mm})$ & Hedelfinger & Summit & Summit & Van \\
\hline $\mathrm{H}_{2} \mathrm{O}$ & --- & $75.6 \mathrm{a}^{\mathrm{z}}$ & $24.8 \mathrm{ab}$ & $33.6 \mathrm{a}$ & $89.2 \mathrm{a}$ \\
$\mathrm{CaCl}_{2}$ & 2.5 & $---\mathrm{y}$ & --- & $12.0 \mathrm{~b}$ & --- \\
& 10 & --- & --- & $8.8 \mathrm{bc}$ & --- \\
& 25 & --- & --- & $6.0 \mathrm{~cd}$ & --- \\
$\mathrm{FeCl}_{3}$ & 0.25 & --- & $36.4 \mathrm{a}$ & --- & $95.2 \mathrm{a}$ \\
& 1 & --- & $9.2 \mathrm{bc}$ & --- & $74.4 \mathrm{a}$ \\
& 2.5 & $20.4 \mathrm{~b}$ & $3.2 \mathrm{c}$ & $2.8 \mathrm{de}$ & $43.6 \mathrm{~b}$ \\
& 10 & --- & $0.0 \mathrm{c}$ & $2.4 \mathrm{de}$ & $2.8 \mathrm{c}$ \\
& 25 & $0.0 \mathrm{c}$ & $0.0 \mathrm{c}$ & $0.4 \mathrm{e}$ & $2.0 \mathrm{c}$
\end{tabular}

${ }^{\mathrm{z}}$ Mean separation within columns by Tukey's Studentized range test, $P=0.05$.

yot determined.

black spots formed on the surface of some fruit. Generally, there were no spots in proximate portions of cheek and suture regions, but spot density increased towards the stylarend. Also, black spots developed in the pedicel cavity adjacent to the pedicel/fruit juncture. The area of these spots increased with incubation time and $\mathrm{FeCl}_{3}$ concentration until significant portions of the fruit surface, particularly in stylar end and pedicel cavity regions, were discolored black at $10 \mathrm{~h}$. Macroscopically, the fruit surface in these areas appeared intact. However, inspection by SEM revealed a fine network of closely spaced cracks that were limited to the cuticle and that did not extend into the exo- and mesocarp (Fig. 6B). In contrast, the cuticle in non-discolored adjacent to discolored regions of the same fruit was crack-free (Fig. 6A).

Larger, macroscopically visible cracks, that occasionally developed after longer periods of incubation in $\mathrm{FeCl}_{3}$, also differed from those of control fruit (Fig. $6 \mathrm{C}$ vs. D). Cracks in control fruit extended deeply into the mesocarp, sometimes as deep as the stony endocarp, but those from fruit in $\mathrm{FeCl}_{3}$ solutions were shallow and confined to cuticle and outermost cell layer(s) of the exocarp (Fig. $6 \mathrm{C}$ vs. D).

\section{Discussion}

Our data demonstrate that some mineral salts markedly decrease water uptake and reduce cracking. Among the most effective salts were $\mathrm{CuCl}_{2}$, $\mathrm{HgCl}_{2}, \mathrm{AlCl}_{3}$ and $\mathrm{FeCl}_{3}$. Effects of $\mathrm{CaCl}_{2}$ on water uptake, however, were inconsistent. In some cultivars rates of uptake were reduced, but not in others (Tables 1 and 4).

The rate of water uptake $(\mathrm{F})$ across the sweet cherry fruit exocarp is a composite quantity depending on several factors (Eq. 2; Nobel, 1999, modified):

$$
\mathrm{F}=\mathrm{A} \cdot \mathrm{J} \cdot \rho=\mathrm{A} \cdot \mathrm{L}_{\mathrm{w}} \cdot \rho \cdot \Delta \Psi
$$

In this equation, $\mathrm{F}\left(\mathrm{kg} \cdot \mathrm{s}^{-1}\right)$ equals the product of the surface area $\left(\right.$ A in $\left.\mathrm{m}^{2}\right)$, the volume flux density of water $\left(\mathrm{J} \mathrm{in}^{3} \cdot \mathrm{m}^{-2} \cdot \mathrm{s}^{-1}\right)$ and the density $\left(\rho\right.$ in $\mathrm{kg}^{\cdot \mathrm{m}^{-3}}$ ) of water. The $\mathrm{J}$, in turn, corresponds to the

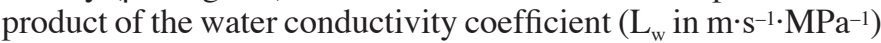
of the exocarp and the gradient in water potential $(\Delta \Psi$ in $\mathrm{MPa})$ across the fruit surface. $\mathrm{L}_{\mathrm{w}}$ is related to the conductance for water uptake $\left(g_{\text {uptake }}\right.$ in $\left.\mathrm{m}^{-1} \mathrm{~s}^{-1}\right)$ used in our earlier study (Beyer and Knoche, 2002; alternate expression: filtration or osmotic permeability, $P_{f}$ in $\mathrm{m} \cdot \mathrm{s}^{-1}$; Nobel, 1999; Schönherr, 1982) by Eq. 3:

$$
L_{w}=g_{\text {uptake }} \cdot \frac{\overline{V_{w}}}{R T}=P_{f} \cdot \frac{\overline{V_{w}}}{R T}
$$

where $\overline{V_{w}}$ (in $\mathrm{m}^{3} \cdot \mathrm{mol}^{-1}$ ) represents the partial molar volume of water, $\mathrm{R}$ (in $\mathrm{m}^{3} \cdot \mathrm{MPa} \cdot \mathrm{mol}^{-1} \cdot \mathrm{K}^{-1}$ ) the universal gas constant, and $\mathrm{T}$ (in $\mathrm{K}$ ) the absolute temperature. Based on Eq. 2, effects on water uptake must be accounted for by effects on $A, L_{w}$, and/or $\Delta \Psi$. Since A remained essentially constant, $\Delta \Psi$ and/or $\mathrm{L}_{\mathrm{w}}$ of the exocarp must have changed. Furthermore, in non-sealed fruit, the pedicel/fruit juncture represents a significant parallel pathway for water uptake (Beyer et al., 2002b) that could also be affected by salts. 


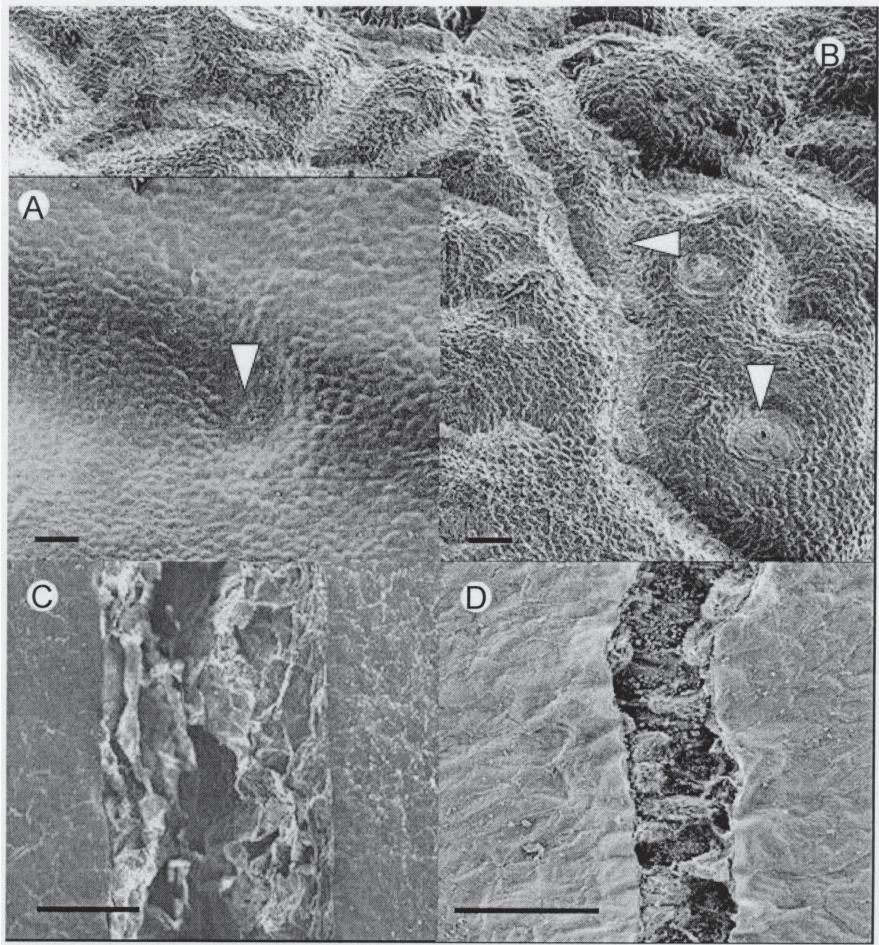

Fig. 6. Micrographs of the sweet cherry fruit surface obtained by scanning electron microscopy. Surface of 'Van' sweet cherry in (A) a non-discolored $(\times 80)$ and $(\mathbf{B})$ discolored region $(\times 60)$ after a 10-h incubation period in 100 $\mathrm{mm} \mathrm{FeCl}_{3}$. Vertical and horizontal arrows indicate stomata and cuticular fractures, respectively. (C, D) Crack in 'Hedelfinger' sweet cherry fruit after a 10 -h incubation period in $(\mathbf{C})$ water $(\times 250)$ or $(\mathbf{D}) 10 \mathrm{~mm} \mathrm{FeCl}_{3}(\times 250)$. Scale bars in A to D $100 \mu \mathrm{m}$.

EFFECTS ONPERMEABILITY OFTHE CHERRY FRUIT EXOCARP.Earlier studies established that $\mathrm{AlCl}_{3}, \mathrm{EuCl}_{3}$, and $\mathrm{FeCl}_{3}$, but not $\mathrm{CaCl}_{2}$, decreased conductance of the sweet cherry exocarp (Beyer et al., 2002a). These effects were related to the cation and the chloride anion had no effect. Beyer et al. (2002a) hypothesized that formation of $\mathrm{Al}$ and Fe oxides and hydroxides caused by a $\mathrm{pH}$ dependent precipitation reaction may be responsible for the marked decrease in conductance. In an aqueous solution of $\mathrm{CuCl}_{2}, \mathrm{Cu}(\mathrm{OH})_{2}$ would form upon hydrolysis. Since the solubility product of $\mathrm{Cu}(\mathrm{OH})_{2}$ is low and likely to be exceeded at the $\mathrm{pH}$ encountered in the apoplast of the exocarp, precipitation would occur resulting in decreased conductance. Similarly, effects of $\mathrm{AgNO}_{3}$ and $\mathrm{HgCl}_{2}$ may also be accounted for by a precipitation reaction. First, deposits of reduced $\mathrm{Ag}$ were demonstrated in the stomatal pore of pear leaves following treatment with $\mathrm{AgNO}_{3}$ (Greene and Bukovac, 1974). Second, $\mathrm{HgCl}_{2}$ is readily reduced to $\mathrm{HgCl}$ (Franke, 1961) and solubility of $\mathrm{HgCl}$ is low. Further support for this hypothesis comes from early work on foliar uptake, where mercurial deposits were observed after treatment of leaves with $\mathrm{HgCl}_{2}$ (Franke, 1961, 1964). The sites, where these deposits occurred, represent regions in the cuticle that are preferentially permeable to polar substances such as the above electrolytes and possibly, water (Schönherr and Bukovac, 1970). Wade (1988) hypothesized that $\mathrm{HgCl}_{2}$ reduced uptake by inhibiting metabolism. However, in our earlier studies, carbonylcyanide and $\mathrm{NaN}_{3}$ did not decrease water transport through excised exocarp segments (Beyer and Knoche, 2002; Knoche et al., 2000). Furthermore, since water transport is a physical process, effects on metabolism are unlikely to affect water uptake. It is interesting to note that mercurials are effective inhibitors of water transport through aquaporins (Tyerman et al., 1999). However, to our knowledge aquaporins have not been identified in plant cuticles. Since water permeability of the sweet cherry fruit exocarp is several orders of magnitude lower than that of the plasma membrane $\left(10^{-8} \mathrm{vs}\right.$. $10^{-4} \mathrm{~m} \cdot \mathrm{s}^{-1}$ for exocarp vs. plasma membranes, respectively; Beyer and Knoche, 2002; Nobel, 1999), effects of $\mathrm{HgCl}_{2}$ on aquaporins in plasma membranes would not explain the marked reduction in water flow rates through the excocarp.

The effects of $\mathrm{NaCl}, \mathrm{BaCl}_{2}, \mathrm{CdCl}_{2}, \mathrm{SrCl}_{2}$, and $\mathrm{ZnCl}_{2}$ that occasionally were significant are unlikely to be accounted for by precipitation, since solubility products of the respective hydroxides are sufficiently high. The mechanism of decreasing water penetration is currently unknown for these salts and may possibly be related to altered mechanical properties of the fruit (see below).

EFFECT ON THE DRIVING FORCE FOR WATER UPTAKE $(\Delta \Psi)$. According to van't Hoff's law (Nobel, 1999), the osmotic pressure of a dilute solute solution is proportional to its concentration and, for electrolytes, proportional to the concentration of ions. Thus, salts decrease the osmotic potential of the donor solution thereby decreasing $\Delta \Psi$. In our experiment (Table 1), salts of trivalent cations should have the largest effect on the osmotic potential and these were indeed among the most effective (Table 1). Assuming complete dissociation and ideal behavior, the maximum decrease in $\Delta \Psi$ due to osmotic effects would amount to $-0.10 \mathrm{MPa}$ for a $10 \mathrm{~mm}$ solution of a salt of a trivalent cation. At a water potential of -1.42 MPa ('Napoleon', Andersen and Richardson, 1982), the maximum decrease in $\Delta \Psi$ due to osmotic effects would be about $7 \%$ of the water control (for water $\mathrm{F}^{\mathrm{II}} / \mathrm{F}^{\mathrm{I}}$ and $\mathrm{F}^{\mathrm{III}} / \mathrm{FI}^{\mathrm{I}}$ were 0.87 and 0.91 , respectively). Hence, ratios of FII/FI and FIII/FI lower than 0.80 and 0.84 , respectively, cannot be accounted for by osmotic effects and must have a different basis (Table 1). Also, osmotic effects would be non-specific and hence, would occur with any salt present in the donor solution.

Alternatively, salts may have altered the $\Delta \Psi$ by altering the fruit's water potential. The sweet cherry fruit exocarp is markedly strained during fruit development (Knoche et al., 2001, 2004; Tukey and Young, 1939) and the turgor pressure generated by the strained exocarp lowers the driving force for water uptake. Increased rigidity of cell walls as a result of a cross-linking of cell wall components by divalent or trivalent cations could therefore decrease water uptake. Several arguments support this hypothesis. First, effects of $\mathrm{CaCl}_{2}$ on fruit firmness are well established (Johnston et al., 2002) and also documented for sweet cherry (Lidster et al., 1978, 1979). Second, analysis of cracking as a function of water uptake demonstrated that for a given amount of water uptake percentage of cracked fruit from $\mathrm{CaCl}_{2}$ and even more so from $\mathrm{FeCl}_{3}$ treatments was always lower than in the control (vertical comparison; Fig. 5 B, D, and F). Accordingly, fruit from $\mathrm{CaCl}_{2}$ and $\mathrm{FeCl}_{3}$ treatments survived higher uptake at a given percentage of cracked fruit than the water control (horizontal comparison; Fig. 5 B, D, and F). If salt effects were limited to water uptake, a single relationship for salt and control treatments would be obtained. This, however, was not the case. Third, cracks that occasionally also formed in fruit incubated in $\mathrm{FeCl}_{3}$ were always shallow and rarely extended into the mesocarp, while those in control fruit often extended deeply into the mesocarp (Fig. $6 \mathrm{C}$ and D).

EFFECTS ON PENETRATION ALONG THE PEDICEL/FRUIT JUNCTURE. $\mathrm{FeCl}_{3}$ had little effect on water uptake along this pathway since penetration into fruit that was sealed except for the juncture was 
reduced by only $17.5 \%\left(\mathrm{FI}^{\mathrm{II}} / \mathrm{FI}^{\mathrm{I}}\right)$ and $13.4 \%\left(\mathrm{~F}^{\mathrm{II}} / \mathrm{FI}^{\mathrm{I}}\right)$. The absence of a larger effect on penetration along the juncture may also account for the decrease in effectiveness of $\mathrm{FeCl}_{3}$ in developing 'Regina' fruit, since juncture penetration markedly increases towards maturity (Beyer et al., 2002b).

Practical implications. From a practical point of view, the effect of $\mathrm{FeCl}_{3}$, but unlikely that of $\mathrm{HgCl}_{2}, \mathrm{AlCl}_{3}$, or other heavy metals, may be useful provided a Fe salt suitable for spray application can be identified. Our data demonstrate that $\mathrm{FeCl}_{3}$ and possibly other $\mathrm{Fe}^{3+}$ salts are effective in decreasing water uptake and reducing fruit cracking in all cultivars investigated. However, some caution is needed. First, our data were obtained in laboratory assays where entire surfaces of whole fruit (this study) or excised exocarp segments (Beyer et al., 2002a) were exposed to Fe containing, donor solutions. Following spray application in the field only a limited portion of the fruit surface would be in contact with spray solution. Based on the proposed mode of action, Fe effects on water uptake would be limited to those portions of the fruit surface in direct contact with solution making maximum coverage an essential requirement for a detectable response. Second, the discoloration observed on fruit incubated in $\mathrm{FeCl}_{3}$ is critical from a consumer's point of view. At present it is not known whether other Fe salts have the same limitation. This would be expected, if the precipitation products formed in the exocarp were the primary cause for discolored fruit. Last, phytotoxicity of the acidic $\mathrm{FeCl}_{3}$ solution and formation of spray residues on fruit are potential problems that would have to be resolved before application of Fe salts in the field can be evaluated as a potential cultural treatment to reduce water uptake and cracking in sweet cherry fruit.

\section{Literature Cited}

Andersen, P.C. and D.G. Richardson. 1982. A rapid method to estimate fruit water status with special reference to rain cracking of sweet cherries. J. Amer. Soc. Hort. Sci. 107:441-444.

Bangerth, F. 1968. Zur Ursache des Platzens von Kirschenfrüchten, p. 198-201. Symp. on Cherries and Cherry Growing. Intl. Soc. Hort. Sci., Institut für Obstbau der Universität Bonn, 25-28 June 1968, Bonn, Germany,

Beyer, M. and M. Knoche. 2002. Studies on water transport through the sweet cherry fruit surface: V. Conductance for water uptake. J. Amer. Soc. Hort. Sci. 127:325-332.

Beyer, M., S. Peschel, H. Weichert, and M. Knoche. 2002a. Studies on water transport through the sweet cherry fruit surface: VII. Fe ${ }^{3+}$ and $\mathrm{Al}^{3+}$ lower conductance for water uptake. J. Agr. Food Chem. 50:7600-7608.

Beyer, M., S. Peschel, M. Knörgen, and M. Knoche. 2002b. Studies on water transport through the sweet cherry fruit surface: IV. Regions of preferential uptake. HortScience 37:637-641.

Bullock, R.M. 1952. A study of some inorganic compounds and growth promoting chemicals in relation to fruit cracking of Bing cherries at maturity. Proc. Amer. Soc. Hort. Sci. 59:243-253.

Callan, N.W. 1986. Calcium hydroxide reduces splitting of 'Lambert' sweet cherry. J. Amer. Soc. Hort. Sci. 111:173-175.

Christensen, J.V. 1996. Rain-induced cracking of sweet cherries. Its causes and prevention, p. 297-327. In: A.D. Webster and N.E. Looney (eds.). Cherries. CAB Intl., Wallingford, U.K.
Considine, J.A. and P.E. Kriedemann. 1972. Fruit splitting in grapes. Determination of the critical turgor pressure. Austral. J. Agr. Res. 23:17-24.

Franke, W. 1961. Ectodesmata and foliar absorption. Amer. J. Bot. 48:683-691.

Franke, W. 1964. Role of guard cells in foliar absorption. Nature 202:1236-1237.

Glenn, G.M. and B.W. Poovaiah. 1989. Cuticular properties and postharvest calcium applications influence cracking of sweet cherries. J. Amer. Soc. Hort. Sci. 114:781-788.

Greene, D.W. and M.J. Bukovac. 1974. Stomatal penetration: Effect of surfactants and role in foliar absorption. Amer. J. Bot. 61:100-106.

Johnston, J.W., E.W. Hewett, and M.L.A.T.M. Hertog. 2002. Postharvest softening of apple (Malus domestica) fruit: A review. N.Z. J. Crop Hort. Sci. 30:145-160.

Knoche, M., S. Peschel, M. Hinz, and M.J. Bukovac. 2000. Studies on water transport through the sweet cherry fruit surface: Characterizing conductance of the cuticular membrane using pericarp segments. Planta 212:127-135.

Knoche, M., S. Peschel, M. Hinz, and M.J. Bukovac. 2001. Studies on water transport through the sweet cherry fruit surface: II. Effect of fruit development on conductance. Planta 213:927-936.

Knoche, M., M. Beyer, S. Peschel, B. Oparlakov, and M.J. Bukovac. 2004. Changes in strain and deposition of cuticle in developing sweet cherry fruit. Physiol. Plant. 120:667-677.

Koffmann, W., N.L. Wade, and H. Nicol. 1996. Tree sprays and root pruning fail to control rain induced cracking of sweet cherries. Plant Protection Quarterly 11:126-130.

Lang, G. and J. Flore. 1999. Reducing rain-cracking in cherries. Good Fruit Grower 50:34-38.

Lidster, P.D., S.W. Porritt, and M.A. Tung. 1978. Texture modification of 'Van' sweet cherries by postharvest calcium treatments. J. Amer. Soc. Hort. Sci. 103:527-530.

Lidster, P.D., M.A. Tung, and R.G. Yada. 1979. Effects of preharvest and postharvest calcium treatments on fruit calcium content and the susceptibility of 'Van' cherry to impact damage. J. Amer. Soc. Hort. Sci. 104:790-793.

Looney, N.E. 1985. Benefits of calcium sprays below expectations in B.C. tests. Good Fruit Grower 36:7-8.

Nobel, P.S. 1999. Physicochemical and environmental plant physiology. 2nd ed. Academic Press, San Diego.

Palade, G.E. 1952. A study of fixation for electron microscopy. J. Expt. Medicine 95:285-298.

Schönherr, J. 1982. Resistance of plant surfaces to water loss: Transport properties of cutin, suberin and associated lipids, p. 153-179. In: O.L. Lange, P.S. Nobel, and C.B. Osmond (eds.). Encyclopedia of plant physiology. Vol. 12B. Springer-Verlag, Berlin, Heidelberg, Germany.

Schönherr, J. and M.J. Bukovac. 1970. Preferential polar pathways in the cuticle and their relationship to ectodesmata. Planta 92:189-201.

Sekse, L. 1998. Fruit cracking mechanisms in sweet cherries (Prunus avium L.) - A review. Acta Hort. 468:637-648.

Tyerman, S.D., H.J. Bohnert, C. Maurel, E. Steudle, and J.A.C. Smith. 1999. Plant aquaporins: Their molecular biology, biophysics and significance in plant water relations. J. Expt. Bot. 50:1055-1071.

Tukey, H.B. and J.O. Young. 1939. Histological study of the developing fruit of the sour cherry. Bot. Gaz. 100:723-749.

Verner, L. 1937. Reduction of cracking in sweet cherries following the use of calcium sprays. Proc. Amer. Soc. Hort. Sci. 36:271-274.

Wade, N.L. 1988. Effect of metabolic inhibitors on cracking of sweet cherry fruit. Scientia Hort. 34:239-248. 